\title{
GAMBARAN KADAR KOLESTEROL TOTAL DARAH PADA MAHASISWA ANGKATAN 2011 FAKULTAS KEDOKTERAN UNIVERSITAS SAM RATULANGI DENGAN INDEKS MASSA TUBUH 18,5-22,9 kg/m²
}

\author{
${ }^{1}$ Mega Amaliah Malik \\ ${ }^{2}$ Yanti M. Mewo \\ ${ }^{2}$ Stefana H.M Kaligis
}

\author{
${ }^{1}$ Kandidat Skripsi Fakultas Kedokteran Universitas Sam Ratulangi Manado \\ Bagian Biokimia Fakultas Kedokteran Universitas Sam Ratulangi Manado \\ Email: megaamaliahmalik@yahoo.co.id
}

\begin{abstract}
Consuming high cholesterol food has risks in increasing blood cholesterol level. The increase of blood cholesterol level is associated with the incident of heart disease. Hypercholesterolemia usually occurs in overweight and elderly but also may occur in normal or underweight and young age. The purpose of this study was to find out the description of blood total cholesterol level at students year 2011 Faculty of Medicine Sam Ratulangi University with Body Mass Index (BMI) from 18.5 to $22.9 \mathrm{~kg} / \mathrm{m}^{2}$. This descriptive study was followed by 31 respondents (9 men and 22 women) and was selected using purposive sampling methode. From this study was to found 23 respondents (74.20\%) have normal blood total cholesterol level and 8 respondents (25.80\%) have borderline high blood total cholesterol level. Conclusion: the description of blood total cholesterol at students year 2011 Faculty of Medicine Sam Ratulangi University mostly in normal level.
\end{abstract}

Keyword: Total cholesterol, students year 2011, BMI 18,5-22,9 kg/m².

\begin{abstract}
Abstrak : Mengonsumsi makanan yang mengandung kolesterol tinggi berisiko meningkatkan kadar kolesterol darah atau hiperkolesterolemia. Kenaikan kolesterol darah sangat berhubungan dengan terjadinya penyakit jantung. Hiperkolesterolemia biasanya terjadi pada orang gemuk atau lanjut usia tetapi tidak dapat menutup kemungkinan gangguan metabolisme ini dapat terjadi pada orang kurus bahkan usia muda. Tujuan penelitian ini adalah mengetahui gambaran kadar kolesterol total darah pada mahasiswa angkatan 2011 Fakultas Kedokteran Universitas Sam Ratulangi dengan Indeks Massa Tubuh (IMT) 18,5-22,9 kg/m². Penelitian ini bersifat deskriptif. Sampel diperoleh dengan metode purposive sampling. Penelitian diikuti oleh 31 orang responden yang terdiri dari 9 orang laki-laki dan 22 orang perempuan dengan IMT 18,5-22,9 kg/m². Hasil penelitian ditemukan 23 orang (74,20\%) memiliki kadar kolesterol darah normal dan 8 orang $(25,80 \%)$ memiliki kadar kolesterol total darah dalam ambang batas tinggi. Simpulan: gambaran kadar kolesterol total darah pada mahasiswa angkatan 2011 Fakultas Kedokteran Unsrat dengan IMT 18,5-22,9 kg/m² sebagian besar memiliki kadar kolesterol total normal.
\end{abstract}

Kata Kunci: Kolesterol total, mahasiswa angkatan 2011, IMT 18,5-22,9 kg/m.

Seiring dengan berkembangnya zaman dan modernisasi yang terus terjadi menyebabkan perubahan pola dan gaya hidup masyarakat terutama di daerah perkotaan. Perubahan pola dan gaya hidup ini salah satunya adalah banyak restoran makan cepat saji yang menjual makanan mengandung kolesterol tinggi dan sedikit mengandung nutrisi. Mengonsumsi makanan jenis ini berisiko terkena penyakit degeneratif. 
Pada penyakit ini fungsi dan struktur dari jaringan atau organ tertentu dapat memburuk dari waktu ke waktu. Penyakit yang termasuk dalam kelompok ini antara lain penyakit jantung koroner (PJK) dan kardiovaskuler. ${ }^{1}$

Penyakit jantung merupakan salah satu penyebab terbanyak kematian di negaranegara maju maupun negara berkembang. Di Amerika Serikat setiap tahun 550.000 orang meninggal, di Eropa 20-40.000 orang dari 1 juta penduduk menderita PJK. $^{2}$ Survei yang dilakukan Departemen Kesehatan Republik Indonesia menyatakan prevalensi PJK di Indonesia dari tahun ke tahun terus meningkat. Berdasarkan hasil Survey Kesehatan Rumah Tangga (SKRT) tahun 1972 terjadi peningkatan dari urutan ke 11 menjadi urutan ke 3 pada tahun 1986 dan menjadi penyebab kematian pertama pada tahun 2005. Propinsi Sulawesi Utara adalah salah satu daerah diantara 30 propinsi di Indonesia yang mempunyai angka kematian tinggi. Data laporan Rumah Sakit Umum Prof. dr. R.D Kandou yang merupakan pusat rujukan rumah sakit di propinsi Sulawesi Utara juga menunjukkan bahwa penyakit kardiovaskular merupakan penyebab kematian utama. ${ }^{3}$

Saat ini penyakit kardiovaskular merupakan salah satu penyebab mortalitas tertinggi di dunia termasuk juga di Indonesia. Menurut Sedyaningsih dalam pidato pembukaan The $20^{\text {th }}$ Annual Scientific Meeting of the Indonesia Heart Association (ASHIMA) penyakit jantung telah menjadi salah satu masalah penting kesehatan masyarakat dan merupakan penyebab kematian yang utama. Berdasarkan data dari World Health Association (WHO) diperkirakan pada tahun 2030 sekitar 23,6 juta orang akan meninggal karena penyakit kardiovaskular. Berdasarkan Riset Kesehatan Dasar atau Riskerdas 2007, menunjukkan bahwa prevalensi penyakit jantung secara nasional adalah 7,2 \%. ${ }^{4}$ Pada tahun 2008 penyakit kardiovaskular telah membunuh 17,3 juta orang, $31 \%$ dari total semua kematian di dunia. ${ }^{5}$

Framingham Heart Study bekerjasama dengan National Heart, Lung, and Blood
Institute (NHLBI) yang dikutip dari Durstine $^{6}$ mendefinisikan kadar kolesterol total darah melebihi $300 \mathrm{mg} / \mathrm{dL}$ akan berisiko tiga hingga lima kali lebih besar mengalami penyakit jantung daripada mereka yang memiliki kadar kolesterol darah 200 mg/dL. Hubungan antara kenaikan kolesterol ini sangat berkaitan dengan terjadinya penyakit jantung.

Kelebihan kolesterol akibat sering mengonsumsi makanan yang mengandung tinggi kolesterol dan kurangnya aktivitas fisik bisa menyebabkan gangguan pada sistem transportasi darah baik secara langsung dan tidak langsung. ${ }^{7}$ Kolesterol berlebih atau biasa yang disebut dengan hiperkolesterolemia umumnya diderita oleh orang gemuk atau orang yang sudah lanjut usia tetapi tidak menutup kemungkian gangguan metabolisme ini dapat menyerang orang kurus bahkan di usia muda. ${ }^{8}$

Di Indonesia prevalensi hiperkolesterolemia pada usia 25-34 tahun adalah 9,3\% sedangkan pada usia 55-64 tahun sebesar $15,5 \%$. Faktor risiko terjadinya antara lain adalah faktor genetik, pola makan dan kurangnya aktivitas olahraga. Laporan WHO menyebutkan bahwa pada tahun 2002, tercatat sebanyak 4,4 juta kematian PJK adalah akibat hiperkolesterolemia atau sebesar 7,9 \% dari jumlah total kematian di usia muda. ${ }^{9}$

Berdasarkan uraian diatas maka penulis tertarik untuk melihat gambaran kadar kolesterol total pada mahasiswa angkatan 2011 Fakultas Kedokteran Universitas Sam Ratulangi (Unsrat) dengan indeks massa tubuh (IMT) 18,5-22,9 kg/m².

\section{METODE PENELITIAN}

Jenis penelitian ini ialah penelitian deskriptif yang dilaksanakan pada bulan Oktober-Januari 2013 di Fakultas Kedokteran Universitas Sam Ratulangi Manado. Sampel dalam penelitian ini berjumlah 31 orang yang diambil dengan cara purposive sampling dengan menggunakan kriteria. Kriteria inklusi yaitu responden bersedia menjadi sampel, sehat, dan IMT 18,5-22,9 $\mathrm{kg} / \mathrm{m}^{2}$ sedangkan kriteria eksklusi yaitu 
seorang atlit dan dalam penggunaan obat yang mempengaruhi kadar kolesterol total. Penelitian ini menggunakan alat Microtoise, timbangan badan dengan tingkat ketelitian $0,1 \mathrm{~kg}$, jarum suntik $2,5 \mathrm{ml}$, tourniquet, APX Pentra 400.

\section{HASIL PENELITIAN}

Berdasarkan hasil penelitian yang dilakukan untuk mengetahui gambaran kadar kolesterol total darah pada mahasiswa angkatan 2011 Fakultas Kedokteran Universitas Sam Ratulangi, diperoleh sebanyak 31 orang dengan indeks massa tubuh 18,5$22,9 \mathrm{~kg} / \mathrm{m}^{2}$. Berdasarkan pengumpulan data pada responden ditemu-kan laki-laki sebanyak 9 orang $(29,04 \%)$ dan perempuan sebanyak 22 orang (70,96\%). (Tabel 1).

Berdasarkan kadar kolesterol total dalam darah, responden yang memilki kadar kolesterol total normal 23 orang $(74,20 \%)$ dan 8 orang berada dalam ambang batas tinggi (25,80\%). (Tabel 2)

Tabel 1. Distribusi responden menurut jenis kelamin

\begin{tabular}{lcc}
\hline $\begin{array}{l}\text { Jenis } \\
\text { Kelamin }\end{array}$ & Jumlah (n) & $\begin{array}{c}\text { Persentasi } \\
(\mathbf{\% )}\end{array}$ \\
\hline Laki-laki & 9 & 29,04 \\
Perempuan & 22 & 70,96 \\
Jumlah & 31 & 100 \\
\hline
\end{tabular}

Tabel 2. Distribusi responden berdasarkan kadar kolesterol dalam darah

\begin{tabular}{lcc}
\hline $\begin{array}{l}\text { Kadar kolesterol } \\
\text { total (mg/dL) }\end{array}$ & Jumlah (n) & $\begin{array}{c}\text { Persentasi } \\
\text { (\%) }\end{array}$ \\
\hline Normal (<200) & 23 & 74,20 \\
Ambang batas & 8 & 25,80 \\
tinggi (200-239) & 0 & 0 \\
Tinggi ( $\geq 240)$ & 31 & 100 \\
Jumlah & & \\
\hline
\end{tabular}

\section{PEMBAHASAN}

Berdasarkan hasil penelitian, kadar kolesterol dalam darah responden didapatkan bahwa dari 31 orang ditemukan kadar kolesterol total darah normal $(<200$ mg/dL) sebanyak 23 orang (74,20\%). Sesuai dengan kepustakaan kadar kolesterol total meningkat sehubungan dengan peningkatan IMT. ${ }^{10}$ Hasil penelitian yang dilakukan Pratama pada tahun 2011 didapatkan hubungan bermakna antara IMT normal terhadap kadar kolesterol normal, yaitu responden dengan IMT normal paling banyak memiliki kadar kolesterol normal. ${ }^{11}$

Pengaruh gaya hidup seperti kebiasaan melakukan olahraga secara teratur merupakan faktor penting untuk mengontrol kolesterol total. Menurut Fatimah dan Kartini, olahraga secara rutin dan teratur dapat bermanfaat terhadap regulasi kolesterol yaitu dapat menurunkan kadar kolesterol total. ${ }^{12}$ Penelitian di Amerika Serikat juga menunjukkan aktivitas fisik secara teratur dapat mempengaruhi kadar kolesterol serum. ${ }^{13}$

Salah satu faktor untuk mengontrol kolesterol total darah yaitu dengan menjaga pola makan. Lebih dari separuh jumlah kolesterol tubuh berasal dari sintesis (sekitar $700 \mathrm{mg} / \mathrm{hari}$ ), dan sisanya berasal dari makanan sehari-hari. ${ }^{10}$ Diet lemak jenuh meningkatkan konsentrasi kolesterol darah 15 sampai 25 persen. Oleh karena itu untuk menurunkan konsentrasi kolesterol darah, mempertahankan diet rendah lemak jenuh sama pentingnya dengan mempertahankan diet rendah kolesterol. ${ }^{14}$ Menurut Depkes 2007 kandungan serat, vitamin dan mineral alami yang diperoleh dapat mencegah penyakit-penyakit yang banyak diakibatkan oleh gangguan kolesterol. ${ }^{15}$ Selama pemasukan makanan seimbang dengan kebutuhan tubuh, maka tidak memberikan pengaruh yang negatif. ${ }^{9}$

Pada Tabel 2 hasil penelitian juga didapatkan kadar kolesterol total darah dalam ambang batas tinggi 200-239 mg/dL sebanyak 8 orang (25,80\%). Peningkatan kadar kolesterol darah dapat menyerang usia muda. ${ }^{15}$ Menurut Nor mulai umur 20 tahun kadar kolesterol pada laki-laki dan wanita akan meningkat. ${ }^{16}$ Faktor risiko yang menyebabkan terjadinya hiperkolesterolemia antara lain adalah kurangnya aktivitas fisik. Kemajuan teknologi tanpa 
disadari telah membuat aktifitas berkurang. Balitbangkes pada data Riskesdas 2007 menunjukkan prevalensi kurangnya aktivitas fisik pada penduduk usia $>10$ tahun mencapai angka $48,2 \% .^{15}$

Selain aktifitas fisik yang berkurang, pola makan yang tidak sehat dan lebih bersifat praktis seperti makanan siap saji maupun junk food yang biasanya banyak mengandung lemak tinggi dan rendah serat, juga berperan dalam terjadinya hiperkolesterolemia. ${ }^{15}$ Hal ini disebabkan karena adanya peningkatan jumlah Asetil-KoA dalam sel hati untuk menghasilkan kolesterol. Jika keadaan ini melampaui batas mekanisme kompensasi tubuh dalam metabolisme lemak, tentunya akan menyebabkan terjadinya hiperkolesterolemia. ${ }^{17}$

Salah satu faktor risiko terjadinya hiperkolesterolemia pada usia muda adalah hiperkolesterolemia turunan atau Familial Hypercholesterolemia. Penyebab tersering dari kelainan gen pengatur homeostatis lemak tubuh yang merupakan kelainan yang terjadi karena adanya mutasi pada gen reseptor LDL yang diturunkan secara autosomal dominan. Berdasarkan banyaknya mutan, dikenal adanya HF homozigot dan heterezigot. ${ }^{18}$ Pada mutasi heterezigot terjadi peningkatan konsentrasi kolesterol plasma total 2 sampai 3 kali lipat yang berperan terhadap peningkatan kadar LDL. $^{19}$

Kolesterol harus dikontrol secara rutin, terutama pada seseorang yang mulai menginjak dewasa. Apabila hasil pemeriksaan kolesterol normal, selanjutnya cukup dilakukan setahun sekali. Tapi apabila kolesterol cukup tinggi, pemeriksaan harus dilakukan setiap tiga bulan. ${ }^{7}$

Penelitian ini memiliki beberapa kelemahan. Kelemahan yang pertama ialah tidak dilakukan pengambilan data mengenai daily food record responden. Hal ini menyebabkan, pada penelitian ini tidak diketahui mengenai pola makan responden, yang mana merupakan salah satu faktor penting menentukan kadar kolesterol total darah. Kelemahan lainnya adalah jumlah responden yang sedikit, sehingga tidak bisa menggambarkan secara keseluruhan kadar kolesterol total pada mahasiswa angkatan 2011 Fakultas Kedokteran Unsrat.

\section{SIMPULAN}

Berdasarkan penelitian yang dilakukan pada mahasiswa angkatan 2011 Fakultas Kedokteran Universitas Sam Ratulangi dengan Indeks Massa Tubuh 18,5-22,9 $\mathrm{kg} / \mathrm{m}^{2}$ disimpulkan bahwa gambaran kadar kolesterol total darah sebagian besar (74,20\%) adalah normal ( $<200 \mathrm{mg} / \mathrm{dL})$ dan sisanya $(25,80 \%)$ dalam ambang batas tinggi (200-239 mg/dL).

\section{SARAN}

1. Bagi responden yang memiliki kadar kolesterol total darah normal, agar selalu menjaga kadar kolesterol total dalam batas normal $(<200 \mathrm{mg} / \mathrm{dL})$ dengan cara mengatur pola makan yang baik, berolahraga secara teratur, dan menghindari faktor-faktor risiko yang dapat menimbulkan masalah kelebihan kolesterol atau hiperkolesterolemia.

2. Responden yang memiliki kadar kolesterol dalam ambang batas tinggi (200$239 \mathrm{mg} / \mathrm{dL}$ ), perlu mengurangi kadar kolesterol dengan cara mengkonsumsi makanan berserat dan menghindari makanan mengandung kolesterol.

3. Perlunya penelitian lebih lanjut dengan jumlah responden yang lebih banyak.

4. Perlunya penelitian lebih lanjut dengan variabel penelitian yang lain misalnya daily food record.

\section{UCAPAN TERIMA KASIH}

Ditujukan kepada dr. Diana S. Purwanto, MLabMed dan dr. Youla A. Assa, MKes selaku dosen penguji 1 dan 2, serta dr. Masinem, SU yang telah memberi masukan dan saran dalam penulisan. Kepada responden yang telah bersedia menjadi subjek dalam penelitian ini. Serta kepada semua pihak yang secara langsung maupun tidak langsung telah menumbuhkan ide atau gagasan dalam pemikiran penulis hingga dapat menyelesaikan artikel ini. 


\section{DAFTAR PUSTAKA}

1. Hidayatulloh A, Nurhasanah A, Irawan E, Firdaus F, Isnaini F, A Novi et al. Hubungan Faktor Resiko Obesitas Dengan Rasio Lingkar Pinggang Pingggul Mahasiswa FKM UI. Asosiasi Keluarga Gizi. [homepage on the Internet]. 2011 [cited 2012 Nov 10]. Available from:http://akgfkmui.files.wordpress.com/2 012/03/jurnal-fixed21.pdf.

2. Melati R, Basuki E, Setianto B. Hubungan Antara Job Strain Dengan Terjadinya Infark Miokard Pada Pasien Pusat Jantung Nasional. Jurnal kardiologi Indonesia [serial online]. 2008 [cited 2012 Nov 10]; 29(1):13-19. Available from:http://indonesia/digitaljournals.org/in dex.php/karidn/article/download/331/327.

3. Kandou GD. Makanan Etnik Minahasa \& Kejadian Penyakit Jantung Koroner. Jurnal Kesehatan Masyarakat Nasional. [homepage on the Internet]. 2012 [cited 2012 oktober 16]. Available From: http://www.jurnalkesmas.org/berita-262makanan-etnik-minahasa-dan-kejadianpenyakit-jantung-koroner.html.

4. Akses Masyarakat Terhadap Pelayanan Kesehatan Jantung Meningkat. Kementrian Kesehatan Republik Indonesia. [homepage on the Internet]. 2012 [cited 12 Nov 2012]. Available from: http://www.bppsdmk. depkes.go.id/index.php?option=com_conte nt\&view=article\&id=173:menkes-aksesmasyarakat-terhadap-pelayanan-kesehatanjantung-meningkat\&catid=38: berita\&ltemid $=82$.

5. Rahajoe AU. The Collaboration In Fighting Hypertension And Its Complications Cardiologist's Prespective. Indonesia Society Of Hypertension. [homepage on the Internet]. 2012. [cited 12 Nov 2012]. Available from: http://www. inash.or.id/article_detail.html?id=34.

6. Durstine L. Kolesterol Tinggi. Yogyakarta: Citra Aji Parama, 2012; p.1-27.

7. Listian L, Purbosari TY. Kadar Kolesterol Total Pada Usia 25-60 Tahun. Electronic Journal UM Surabaya [serial online]. 2010 [cited 2012 Oktober 16]; 5(1):36-40. Available from:http://apps. umsurabaya.ac.id/jurnal/gdl.php?mod=bro wse\&op=read\&id=umsurabaya-1912linalistia-7.

8. Fitnella V. Awas Bahaya Laten Kolesterol. Yogyakarta: Azna Books, 2009; p.49-51.
9. Brata HW. Hubungan Pola Makan, Obesitas, Keteraturan Berolahraga \& Kebiasaan Merokok Dengan Kejadian Hiperkolesterolemia. Unismus digital library. [homepage on the Internet]. 2010. [cited 2012 okt 16]. Available from: http://digilib.unimus.ac.id/gdl.php?mod=br owse\&op=read\&id=jtpumimus-gdl-harsa nawis-5211\&PHPSESSID=1e67af6ffa4bdd 962b254ed311c991538.

10. Idapola SSJ. Hubungan Indeks Massa Tubuh Dengan Keadaan Biokimia Darah Pada Karyawan PT. Asuransi Jiwa Bumi Asih Jaya [Skripsi]. Jakarta, Depok: Fakultas Kesehatan Masyarakat Univesitas Indonesia; 2009.

11. Pratama L. Hubungan Antara Indeks Massa Tubuh Terhadap Profil Lipid Pada Karyawan PT.United Tractors, Tbk Tahun 2011 [Skripsi]. Jakarta: Fakultas Kedokteran Universitas Pembangunan Nasional Jakarta; 2012.

12. Fatimah S, Kartini A. Senam Aerobik \& Konsumsi Zat Gizi Serta Pengaruhnya Terhadap Kadar Kolesterol Total Darah Wanita. Portal Perpustakaan Online. [homepage on the Internet]. 2011 [cited 2013 jan 14]. Available from: http://i-lib. ugm.ac.id/jurnal/detail.php?dataId=11228.

13. Fan AZ, Ham SA, Muppidi SR, Mokdad AH. Validation of reported physical activity for cholesterol control using two different physical activity instruments. Vascular Health and Risk Management. 2009;5:649-61.

14. Guyton AC, Hall JE. Metabolisme lipid. In:Guyton AC, Hall JE editors. Buku Ajar Fisiologi Kedokteran (Edisi Ke-11). Jakarta: EGC, 2007; p.882-94.

15. Andriani E, Damanik R, Ekayanti I. Hubungan pemberian kapsul serbuk daun torbangun terhadap total kolesterol. Jurnal Teknologi Industri Boga dan Busana [serial online]. 2012 [cited 2013 Jan 14];3 (1):1422. Available from: http://journal. um.ac.id/index.php/tibbs/article/view/2919.

16. Nor MDBM. Proporsi Indeks Massa Tubuh (IMT) Pederita Penyaki Jantung Koroner (PJK) di RSUP Haji Adam Malik [Skripsi]. Medan: Fakultas Kedokteran Universitas Sumatera Utara; 2010.

17. Ernawati DI. Pengaruh lama stress \& diet Atherogenik terhadap pembentukan foam arteri Cerebral otak tikus jantan galur spargue dawey [Skripsi]. Malang: 
Universitas Negeri Malang; 2000.

18. Brown MS, Goldstein JL. Gangguan Metabolisme Antara. In: Isselbacher, Braunwal Wilson, Martin, Fauci, Kasper, editors. Harrison Prinsip-Prinsip Ilmu Penyakit Dalam Volume 5 (Edisi ke-13).
Jakarta: EGC, 2000; p.2284.

19. Prawitasari $T$, Sastroasmoro $S$, Sjarif DR. Skrinnimg Sistematik Terhadap Hiperkolesterolemia Familial Pada Anak. Sari Pediatri. 2011;13(2):152-8. 